\title{
PerCursos
}

\section{A sustentabilidade encontra a teoria situacionista na cidade: um relato de détournement e a retomada de uma ecotopia justa e rebelde ${ }^{1}$}

\begin{abstract}
Resumo
A Cidade Situacionista não pôde ser criada. Sua concepção e construção exigiram a participação de uma população anarquista pós-revolucionária (SADLER, 1999). Porém, os situacionistas acreditavam que a materialidade desta cidade realmente pudesse fomentar a revolução. Um paradoxo: a Utopia. Na trilha para um desafio à ortodoxia situacionista, o arquiteto Constant projetou a Nova Babilônia [New Babylon], uma cidade anticapitalista que prefigurava um urbanismo unitário participativo e lúdico. Suspensa acima da "natureza", no entanto, a Nova Babilônia não era uma ecotopia: não ofereceu nenhuma esperança de ou na (re)integração. No calor do desmantelamento da Internacional Situacionista e do refluxo da onda revolucionária de 1968, um coletivo disperso de minorias ocupou uma antiga base militar: em Copenhagen, a "cidade-livre" Christiania foi fundada. Fadada a uma luta perpétua com o estado holandês, a existência de Christiania vem sendo ameaçada desde então. A comunidade desenvolveu um anarquismo singular de base local eivado de tensões: não violento e "enfurecido", quiescente e revolucionário, ecológico e desprovido de recursos. Neste artigo, assevero que a noção de urbanismo sustentável foi retomada pela sociedade do espetáculo (DEBORD, 1983). Para fazer ressurgir a cidade sustentável (WHITEHEAD, 2011), proponho uma mirada à teoria situacionista e ao détournement, concentrando-se em Christiania, especialmente, também, com vistas a uma alternativa.
\end{abstract}

Palavras-chave: Ecotopia. Teoria situacionista. Urbanismo sustentável. Christiania.

DOI: $10.5965 / 1984724620422019310$

http://dx.doi.org/10.5965/1984724620422019310

\author{
Kelvin Mason \\ Professor da Cardiff University, \\ Escola de Planejamento e \\ Geografia. \\ Reino Unido \\ kelvin.john.mason@gmail.com
}

Tradução

Sergio Ricardo Alves de Oliveira Doutor em Serviço Social pela Universidade Federal do Rio de Janeiro - UFRJ.

Professor da Universidade do Estado do Amapá - UEAP. Brasil serge.rk@gmail.com

\footnotetext{
${ }^{1}$ Texto publicado em justice spatiale | spatial justice. Também traduzido e publicado sob o título Quand la durabilité rencontre le situationnisme en ville: une histoire de détournement et la résurrection d'une Ecotopie juste et rebelle, traduction: Frédéric Dufaux, justice spatiale | spatial justice, n. 5, dez. 2012-dez., 2013
} 


\title{
Sustainability meets situationism in the city: a tale of détournement and the resurrection of a just and rebellious Ecotopia
}

\begin{abstract}
The Situationist City could not be built. Both its conception and construction required the participation of a post-revolution anarchist population (SADLER, 1999). Yet the Situationists believed that the materiality of such a city could actually foment revolution. Paradox: Utopia. Defying Situationist orthodoxy, the architect Constant modeled New Babylon, an anticapitalist city prefiguring a playful and participatory unitary urbanism. Suspended above "nature", however, New Babylon was no Ecotopia: It offered no hope of or in (re)integration. In the wake of the disbanding of the Situationist International and the passing of the revolutionary moment of 1968, a loose collective of "othered" people occupied a former barracks site: In the midst of Copenhagen, "Freetown" Christiania was born. Locked in perpetual struggle with the Danish state, Christiania's existence has been under constant threat ever since. The community has developed a particular place-based anarchism infused with tensions: non-violent and "spiky", quiescent and revolutionary, ecologically-minded and resource poor. In this paper, I assert that the notion of sustainable urbanism has been recuperated by the society of the spectacle (DEBORD, 1983). To resurrect the sustainable city (WHITEHEAD, 2011), I propose a turn to situationism and that city's détournement, looking to Christiania particularly for the threat of a good example.
\end{abstract}

Keywords: Ecotopia. Situationism. Sustainable urbanism. Christiania. 


\section{Introdução}

Se uma mirada às questões de urbanismo utópico propõe-se crítica, ao contrário de compensatória e, ao mesmo tempo, busca evitar fornecer figuras consoladoras para reavivar espíritos banalizados pelo cinismo político contemporâneo, então as características transgressoras e revolucionárias devem ser enfatizadas. Tal espírito pode nos fazer retornar para a potência provocativa do campo (PINDER, 2002).

Para ser verdadeiramente transgressoras, e evitar recair em fantasia reacionária, as ecotopias necessitam enfatizar processos e espaços heurísticos, em lugar de formular modelos. Deveriam basear-se em relações econômicas e sociais existentes e evitar constituir mera forma de abstração desvinculada dos processos e situações operantes no mundo "real" contemporâneo (PEPPER, 2005).

A Cidade Sustentável está morta. Seu obituário foi escrito (WHITEHEAD, 2011). Com a Cidade Sustentável deixa-se para trás um paradigma utópico, o Desenvolvimento Sustentável, incapaz de sobreviver sem seu centro urbano. Com a ultrapassagem do urbanismo sustentável também, vai-se para além de uma concepção geográfica de justiça, com o potencial para transcender fronteiras de tempo, espaço e materialidade (BULLEN; WHITEHEAD, 2005). Certamente, a Cidade Sustentável não deveria percorrer gentilmente esta noite generosa; precisamos furiosamente atacar a morte da luz (THOMAS, 1937). Então, como ressuscitar a Cidade Sustentável? Como fazer dela um espaço político participativo para o bem comum (SANDEL, 2010), um espaço de sustentabilidade ambiental e de justiça (AGYEMAN; BULLARD; EVANS, 2003), mas também um espaço de liberdade, diferença, dissenso, de ironia e graça (CHATTERTON, 2006, MOUFFE, 2005, SZERSZYNSKI, 2007, MERRIFIELD, 2011). Em lugar de tentar fazer ressurgir uma cidade sustentável, não seria necessário um novo "paradigma de ecodesenvolvimento urbano"? (WHITEHEAD, 2011). A cidade sustentável já não era uma noção muito envolvida com as relações de dominação, exploração e sujeição? Ainda como uma forma de resistência perante a autoridade, mesmo considerando-se uma erosão corporativa de seus princípios, a cidade sustentável não venceu seu prazo de validade? Já não é teoricamente ultrapassada? 
Capten Cyboli traçou um mapa de sua deriva ${ }^{2}$ por Christiania (Figura 1), nos restos de cerveja sobre a mesa que ocupou em Woodstock, o bar que era o centro social nevrálgico da Freetown. Há uma estória que diz que quando Bob Dylan tocou em Den Grå $\mathrm{Hal}^{3}$ pediu um coquetel extravagante ali, e disseram a ele que havia cerveja. Mas por que Capten Cyboli esteve aqui neste enclave de Christiania, cercado pelo antipático "Hopenhagen", enclausurado por um estado Holandês hostil?4 Era este um lugar apropriado para um combatente que mais tarde serviu ao Clandestine Insurgent Rebel Clown Army [Exército de Palhaços Rebeldes e Insurgentes Clandestinos] ${ }^{5}$, contra as forças coercivas do mesmo estado mobilizado ao serviço do capital ${ }^{6}$ ? Por que ele quis encontrar guarida em um canto escuro deste bar, zelando por sua cerveja e confabulando sobre a morte e o potencial ressurgimento da Cidade Sustentável?

\footnotetext{
${ }^{2}$ Acompanhando a noção situacionista de deriva ou dérive, as pesquisas de Cyboli concentram-se em um intento político ativista, i. e., intencionam radicalizar o paradigma de urbanismo sustentável. Na qualidade de principal método da psicogeografia situacionista, a deriva facilita "o estudo de ambiências urbanas em termos de seus efeitos nas emoções e no comportamento" (PINDER, 2009, p. 147).

3 Den Grå Hal (The Grey Hall) é a maior casa de shows de Christiania; uma antiga arena militar de treinamento com cavalos, acomoda aproximadamente 1.500 pessoas e celebra o Natal servindo alimentos para os mais pobres de Copenhagen.

${ }^{4}$ Deve-se dizer que esta visita de Cyboli a Christiania correspondeu à Cúpula COP15, vinculada às Nações Unidas, realizada em Copenhagen, em novembro de 2009. Na COP15, Siemens e Coca-Cola rotularam a cidade anfitriã "Hopenhagen", sem qualquer ironia. "No centro de Copenhagen, a Siemens estabeleceu sua cidade simulada, inteiramente iluminada em um verde falseado. Lá eles exaltaram as qualidades de uma gama de tecnologias insustentáveis desde carros elétricos esportivos super-rápidos a biocombustíveis. Pôsteres da Coca-Cola anunciam o produto inundado em exploração e açúcar da megacorporação como ‘Esperança na Garrafa!”’ (MASON, 2010).

${ }^{5}$ Disponível em <http://www.clownarmy.org/>. Vários acessos.

${ }^{6}$ Capten Cyboli é a identidade ativista secreta do autor, apenas, sendo um palhaço. O segredo é, claro, conhecimento público. Traduzido para o inglês, o nome significa "O capitão não fala coisa com coisa", um interessante paralelo com o narrador em Utopia de Thomas More, Raphael Hythloday, cujo nome em grego sugere um "especialista em absurdos” (PINDER, 2005a, p. 17).
} 
Figura 1 - Mapa de Christiania (por Kelvin Mason)

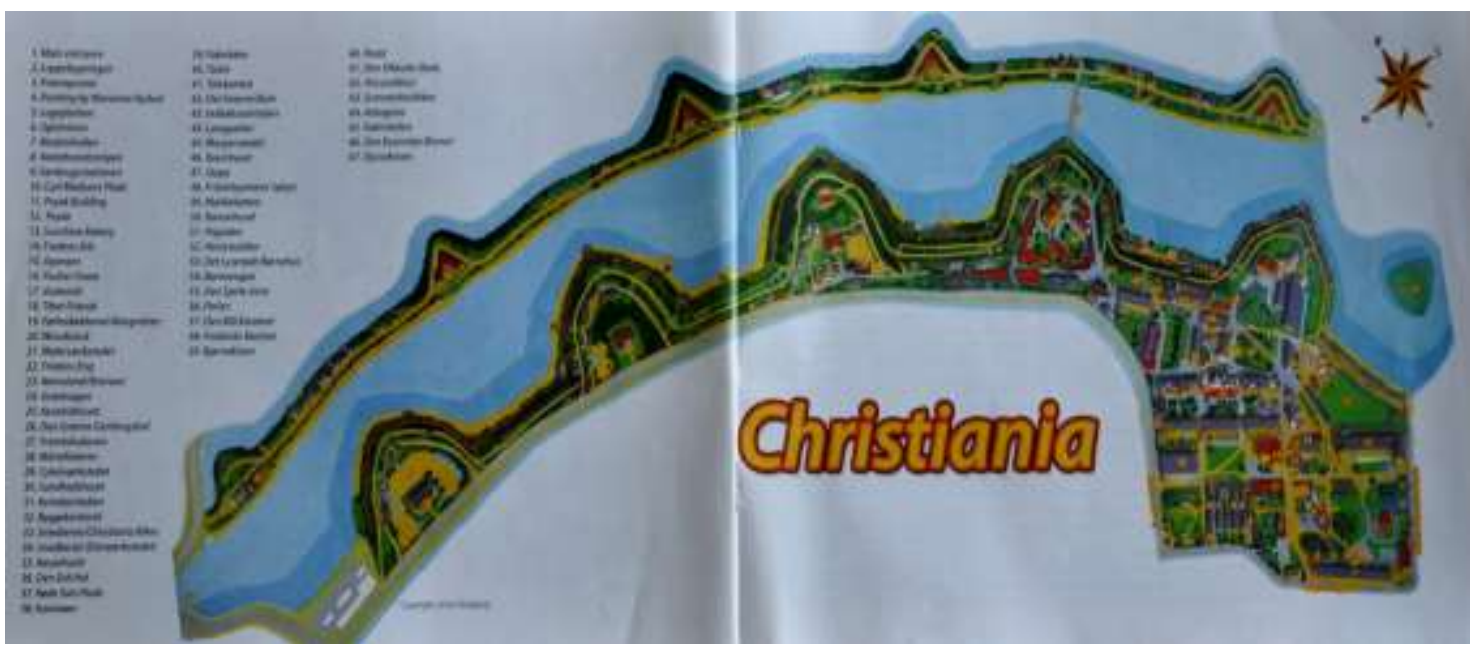

Você está procurando por traços de ecotopia, lembrou-lhe O Provocador7, indo em direção à mesa e sugando a cerveja. Então, aparentemente você me diz em seus raros momentos de lucidez que sua premissa é a de que a utopia, vista como imaginação radical, deve transcender o antropocêntrico e tornar-se Ecotopia. Deve ser uma visão que atue na direção não apenas da raça humana, mas também da natureza mais ampla. Além disso, você afirma que "a cidade" é fundamental não apenas para a habitação da humanidade agora e no futuro, mas também por constituir o núcleo a partir do qual emana uma política que inclui proteção para a natureza mais ampla. Desse modo, os lugares mais significativos na Ecotopia não serão ecovilas ou comunas rurais, mas Ecópolis, a cidade verde do futuro. Ecópolis não corresponderá à imaginação atual de uma Cidade Sustentável, uma vez que tal visão é limitada pela lógica do capitalismo, da governança, da burocracia e do cientismo: a modernização ecológica empregada em concepções oficiais de Cidade Sustentável aparta-se da justiça social (BUTTEL, 2000; HUBER, 1985; MURPHY, 2000; MOL; SPAARGAREN, 2000; MOL; SONNENFELD; SPAARGAREN, 2010; FISHER; FREUDENBURGH, 2001); esta não pode ser verde em um sentido ambiental genuíno, nem igualitário. Para desafiar esta corrupção, creio que “recuperação" é seu termo escolhido (DEBORD, 1983). Ecópolis deveria recorrer à lógica

\footnotetext{
7 "O Provocador" é a evocação de Cyboli para o espírito de Sócrates; parte de uma metodologia de autoavaliação e reflexão. $O$ método socrático é dialético e envolve pessoas que se interrogam para esclarecer ideias e estimular o pensamento crítico. Muitas vezes um envolvido tentará fazer com que o outro caia em contradição.
} 
impossível dos situacionistas para encarar de frente a racionalidade opressiva que domina o planejamento espacial, a arquitetura e até a escolha de materiais de construção. Então, você vai recorrer à noção de urbanismo unitário dos situacionistas, bem como à Nova Babilônia de Constant Nieuwenhuys, o artista holandês que se tornou um arquiteto situacionista, para novamente imaginar a cidade sustentável por meio de sua materialidade. Mas, refresque minha memória, como exatamente a justiça atua?

A lacuna nas conceituações da Cidade Sustentável é um espaço que a justiça deve ocupar, propôs Cyboli. Ao adotar uma perspectiva situacionista sobre a Ecópolis, busco ressaltar este espaço e, ainda mais importante, propor como poderia ser construído - não como alguma variedade de imaginação utópica desconectada da realidade, mas construído a partir de todos os aquis-e-agoras de nossas cidades, através de práticas cotidianas das pessoas que reivindicam o direito de atuação como ativistas e artistas, construtores e tipos brincalhões; quem pode formular perguntas significativas na tessitura das chamadas cidades sustentáveis, proferindo: “Onde está a justiça?”. E começar a responder a própria pergunta, começando a produzir justiça social e materialmente no seio da cidade. Exemplo? Proponho que construamos moradia de bobina de palha para os sem-teto nos portais da cidade; que construamos em padrões Passivhaus $^{8}$, sem carbono e sem desperdício. Depois, desafiemos as autoridades da Cidade Sustentável a destrui-las, estimulando a existência de novos sem-teto, a destruir a arquitetura que, enfim, contribui para alcançar o desafio milenar da mudança climática9. Em busca de visões de Ecotopia, me voltarei tanto para exemplos literários como do mundo real de Ecópolis. É por isso que perambulo por Christiania, sentindo-a. É por isso que vou considerar os camps for climate action [acampamentos para ação climática]

\footnotetext{
8 O Padrão Passivhaus reduz drasticamente as exigências de resfriamento ou aquecimento espacial enquanto mantém condições internas confortáveis. Disponível em <http://www.passivhaus.org.uk>. Vários acessos.

${ }^{9}$ Como um precedente para esta ação, uma roundhouse (um eco-lar com estrutura de madeira, tijolos de madeira, paredes de vidro reciclado e teto de gramado de palha; com energia solar e turbina eólica para a alimentação elétrica, vasos sanitários de compostagem e caniçais para o sistema de esgoto) construída sem permissão de planejamento em Pembrokeshire, País de Gales, conseguiu sobreviver às tentativas das autoridades para removê-la a partir de pressões normativas combinadas (o governo galês é constitucionalmente comprometido com o Desenvolvimento Sustentável) enquanto os apoiadores prostravam seus corpos em linha quando a polícia e os oficiais de justiça chegavam. Disponível em $<$ http://thatroundhouse.info/>. Vários acessos.
} 
urbanos, no Reino Unido, além do protesto de Brian Haw, do lado de fora das Câmaras do Parlamento, em Londres. Permissão de espaço, diria mais: centros sociais, estandes, cidades de tendas, grafites, anúncios subversivos e ações como Reclaim the Streets... E, claro, houve o movimento Occupy e a Primavera Árabe, principalmente a Praça Tahrir como o ponto focal da sublevação egípcia em 2011. Não faço distinção especial entre as ações políticas e a habitação, referindo-me à coerção do estado como o obstáculo que bloqueia sua coextensão. Como propõe Stuart Hodkinson, quanto à luta pela alteridade da moradia?

O objetivo de longo prazo desta estratégia seria o de criar uma massa crítica de diversificadas intervenções táticas e estratégicas para: bloquear a privatização e a gentrificação, interromper o fechamento de instalações comunitárias e ocupar terras para aceder a lugares no conselho local. Estas táticas forçariam a produção de concessões do estado e do capital, além de auxiliar na reafirmação da campanha de moradia. Manter todo este movimento até que se alcançasse um ponto em que um futuro indefinido fosse guiado apenas por princípios dos comuns (HODKINSON, 2010, p. 254).

\section{Mergulhando na metodologia}

Sejamos claros, O Provocador interrompeu: sua hipótese é que o conceito e as práticas de sustentabilidade, especialmente a Cidade Sustentável, são despolitizados pela lógica da modernização ecológica, incluindo as mais recentes noções de capacidade adaptativa e de resiliência (GALLOPIN, 2006). O espírito radical da sustentabilidade, entendido como a maneira mais igualitária de se viver aqui-e-agora bem como o lá-eentão, foi fagocitado pelo capitalismo neoliberal: a Cidade Sustentável, como um projeto, está sendo esvaziada de liberdade; ela se torna um lugar sem justiça ou comunidade real, destituída de espaço público para a política - assim como para o lúdico. E você pensa que a teoria situacionista pode fazer ressurgir a Cidade Sustentável via uma participação apaixonada, a qual se põe para além da defesa do princípio de subsidiariedade de Agyeman e Evans, por meio do qual as decisões devem ser tomadas tão próximas quanto 
possível do cidadão (AGYEMAN; EVANS, 2004): você crê que a decisão deve ser tomada pelo cidadão. Mas, espere: a teoria situacionista e a sustentabilidade não são antitéticas. O urbanismo unitário não corre contra o urbanismo sustentável? A Nova Babilônia poderia realmente ser uma cidade sustentável, sua Ecópolis?

A literatura atual enxerga a Cidade Sustentável especialmente como um campo de governança, diz Cyboli; seu planejamento espacial e sua arquitetura são concebidos em afinação com estruturas administrativas e políticas existentes ou razoavelmente reformadas (EVANS et al., 2005). Entretanto, se é para tomar o desafio de transformar socialmente, economicamente e ambientalmente o espaço urbano, defendo que o paradigma do urbanismo sustentável deve ser radicalizado uma vez mais. A participação democrática plena - uma política normativa do bem comum - é crucial para a concepção e construção de uma Ecópolis justa. Para analisar o encontro da teoria situacionista e a sustentabilidade na cidade, recorro à teoria da produção do espaço de Lefebvre (LEFEBVRE, 1991). Lefebvre procede a partir de "três processos de produção dialeticamente interconectados" (SCHMID, 2008, p. 42):

i. Representações do espaço (o concebido) - abstrações racionais e científicas; o espaço do capital, concebido por profissionais como urbanistas, arquitetos, geógrafos e especuladores imobiliários, “encontrar 'a expressão objetiva' em monumentos, torres, fábricas, blocos de escritórios, bem como o 'autoritarismo político e burocrático imanente ao espaço repressivo"' (MERRIFIELD, 2002, p. 174).

ii. Espaço representacional ou espaços de representação (o vivido) - espaços vividos, repletos de paixão; intuitivos, fragmentados e dinâmicos, os espaços cotidianos da experiência e das situações da imaginação, da fantasia e da possibilidade transgressora; espaços contingentes e criativos 'mantidos vivos e acessíveis pelas artes e pela literatura' (SHIELDS, 2009).

iii. Práticas espaciais (o percebido) - espaço percebido, acessível aos sentidos físicos - "as práticas espaciais estruturam a realidade cotidiana, bem como a realidade social mais ampla; inclui rotas, redes e padrões de interação que vinculam lugares designados para trabalho, jogo e lazer"' (MERRIFIELD, 2002, p. 175). 
Segundo Christian Schmid (Cyboli continuou, depois de virar toda a cerveja), “Lefebvre integra as categorias da cidade e do espaço em uma única teoria social abrangente, permitindo um entendimento e uma análise dos processos espaciais em diferentes níveis" (SCHMID, 2008, p. 27). Para Lefebvre, o espaço não é passivo, não é uma superfície sobre a qual atividades são reproduzidas. Em vez disso, o espaço se produz, e por isso é um agente na reprodução da vida social; ou ainda, a produz de modos distintos: a produção do espaço é constante, fluida e viva. A participação na produção do espaço detém um potencial emancipatório, a chance de interromper a reprodução do espetáculo do capitalismo. Os espaços representacionais são os locais onde as ideias inovadoras sobre a sociedade e o futuro podem ser produzidos; espaços os quais, como Andy Merrifield sugere, podemos "reivindicar, para seus cidadãos" (MERRIFIELD, 2002, p. 181). Então, tenho especial interesse na mediação do espaço representacional e nas representações do espaço por meio das práticas sociais, explicitamente no potencial para práticas de protesto e arquitetura da cidade, com vistas ao desmantelamento do "plano", de forma a produzir espaços de possibilidades ampliadas.

\section{Da utopia à ecotopia: uma transição crítica}

Vagando próximo a um braseiro na noite fria de Pusher Street ${ }^{10}$, Cyboli escreveu em seu caderno (feito de papel reciclado com uma capa diagramada com pneus de carros velhos): onde a sustentabilidade encontra os situacionistas na cidade, o valor comum é o utopismo. Há recentemente um surto de interesse pela noção de utopia, especialmente pelas de utopias urbanas e muito transgressoras do aqui e do agora (MILES, 2005; SPANNOS, 2008; CARLSSON, 2008; COVERLEY, 2010; (ARLSSON; MANNING, 2010). Em In defence of utopian urbanism [Em defesa do urbanismo utópico], David Pinder assevera que "uma perda das perspectivas utópicas em sua integralidade reserva consequências culturais e políticas perturbadoras, das quais não são menores o debilitamento do

\footnotetext{
${ }^{10}$ Uma via de Christiania "infame" pela venda de maconha em várias formas - erva, misturas, biscoitos, baseados prontos... Os pushers impõem uma proibição quanto a fotografias na Pusher Street, enquanto as três regras básicas de Christiania incluem o banimento de drogas pesadas (assim como da violência, armas e manifestações de gangues).
} 
pensamento crítico e o afastamento em relação ao momento antecipatório da crítica" (PINDER, 2002, p. 230, grifo no original). Ele vincula esta perda com uma forte paralisia no debate intelectual (JACOBY, 1999) e se posiciona contra o abandono das perspectivas utópicas urbanas, defendendo, ao contrário, uma retomada de seus potenciais críticos. Pinder vê o impulso utópico como uma parte indelével do espírito humano, conectando a supressão contemporânea deste impulso com o fracasso do socialismo, bem como com o declínio do urbanismo modernista (SANDERCOCK, 1998). Ele recorre, sobretudo, à obra de David Harvey para afirmar o potencial, para o pensamento urbano criativo, de transformação progressiva das cidades e dos processos de urbanização, em lugar de aceitá-las como distópicas, espaços a ser ignorados em concepções de um futuro desejável, analisadas somente em termos de práticas elitistas de escape da cidade do aqui e do agora. Um pensamento urbano criativo, Pinder sugere, significa fazer a pergunta crucial de John Gold: “que tipo de cidade para qual tipo de sociedade?”11

Pinder adota uma visão histórica dos urbanismos utópicos que permitiram visões de como a cidade poderia ser. Ele cita a tese de Kevin Robbins de que a crise da cidade e da urbanidade está associada com a escala de problemas sociais e físicos, "incluindo as maneiras pelas quais a desigualdade, a segmentação e a alienação foram inscritas nas paisagens urbanas contemporâneas" (PINDER, 2002, p. 232). Pinder analisa o utopismo na história e na literatura, ressaltando o autoritarismo com o qual ele pode ser investido e, portanto, as consequentes manifestações distópicas. Ele sustenta que um urbanismo utópico crítico pode contra restar o cinismo, bem como o pessimismo político dominante, por via de suas qualidades potencialmente transgressoras e disruptivas: o urbanismo utópico não precisa ser nem compensatório, nem autoritário. Pinder sugere que o potencial de desenvolvimento de "modos de urbanismo crítico e transformativo abertos, dinâmicos e longe de serem compensatórios, almejam afastar o que foi dado como certo, interromper o espaço e o tempo e abrir perspectivas do que poderia ser" (PINDER, 2002, p. 229). Não enxergando o urbanismo utópico como uma visão unificadora ou um projeto

\footnotetext{
${ }^{11}$ Observo aqui a ressonância com a pergunta de Doreen Massey: "Pelo que este lugar luta?" (MASSEY, 2007).
} 
emancipatório específico, Pinder sugere a busca do possível nas condições atuais como uma maneira de produção múltipla de intervenções no espaço e no tempo.

David Pepper afirma que o utopismo permeia os discursos ambientais contemporâneos, sejam radicais ou reformistas, em que estes termos se vinculam à superação e à mitigação do capitalismo, respectivamente (PEPPER, 2005). Pepper considera a transgressividade da noção de utopia, quer dizer, seu potencial em auxiliar na criação de uma sociedade ecológica (idem). Recorrendo a Callenbach (1975), este apelida o utopismo ambiental de "ecotopismo" e observa que: “Há um largo consenso entre perspectivas ecotópicas diversas sobre o que deveria constituir a ecotopia, deixando-se pouco espaço para o provisório e o reflexivo" (PEPPER, 2005, p. 18). Valendo-se de A blueprint for survival [Um plano de sobrevivência] (GOLDSMITH, 1973 apud PEPPER, 2005, p. 18), Pepper reclama os princípios subjacentes a este consenso, que são: mínima interferência nos processos ecológicos; máxima conservação de energia e materiais; arregimentação populacional, cuja perda deveria ser igualada e não excedida; um sistema social no qual as pessoas aceitarão as três regras básicas (PEPPER, 2005, p. 8).

Com base em Sargisson (2000a, 2000b), Pepper defende que o utopismo construtivo deve afinar nossa crítica da sociedade existente, criando "espaços livres" que catalisam a mudança social. O ecotopismo transgressor é definido como um espaço para o questionamento do status quo e para um pensamento distinto; não esboça nenhum plano universal para a Utopia. Pepper faz diferenciação entre as utopias concretas e abstratas, sendo que as primeiras transcendem os domínios da fantasia porque são derivadas da teoria social crítica. Ele considera a teoria e a prática situacionistas um movimento radical com um aspecto utópico. Havendo proposto os princípios fundamentais da ecotopia, a crítica de Pepper das ecotopias escritas destaca um número de potenciais traços reacionários, incluindo: falta de escopo para a coexistência de diferentes crenças e práticas ${ }^{12}$; uma tendência "ludita" em direção a um "primitivismo futurístico", i. e., um retorno ao pré-moderno; um ecocentrismo altamente ecológico que tenciona construir a ecotopia como sinônimo de uma distopia humana, em que a

\footnotetext{
${ }^{12}$ Observo aqui a "Cidade Soul", a segregação voluntária da população negra na ecotopia de Callenbach (1975).
} 
humanidade perece enquanto (o restante) da natureza prospera; um pós-materialismo que peca em não criar espaço para os despossuídos e oprimidos contemporâneos. Para Pepper, estes traços "sugerem que o ecotopismo carece de fundamentação quanto às relevantes condições socioecológicas reais, e esta limitação diminui seu potencial transgressor" (PEPPER, 2005, p. 11). A crítica da modernização ecológica de Pepper aponta que se trata de uma ecotopia abstrata, não transgressora: “o ideal utópico social democrático de difundir riqueza e poder via economias de mercado reguladas contradiz a dinâmica capitalista de concentração de riqueza e poder" (PEPPER, 2005, p. 17). Ao citar especificamente o fracasso significativo de Kyoto, Pepper assevera que o ideal social democrático de regulamentação global do ambiente não é exequível no capitalismo ${ }^{13}$. Para Pepper, “o social-democrático e a 'terceira via' que tencionam produzir um capitalismo ambientalmente são, humano, solidário e igualitário se direcionam para o fracasso total” (PEPPER, 2005, p. 18). Adotando a noção de David Harvey de que o socialismo precisa de um "otimismo do intelecto" (HARVEY, 2000 PEPPER, 2005), Pepper propõe que o ambientalismo radical tem um déficit paralelo. Ele reconhece "muitas características em comum" entre algumas expressões do utopismo socialista e do ecotopismo radical, as quais reverberam com o ceticismo pós-moderno em sua abordagem mais atenta da ciência e da "perfectibilidade social". Pepper conclui que o idealismo e as avaliações pouco realistas das dinâmicas socioeconômicas existentes limitam o potencial transgressor do ecotopismo.

\section{Cidade sustentável e urbanismo sustentável}

Cyboli saiu de Woodstock, tendo passado uma hora com um cristianita ${ }^{14}$ aleatório, brindando-o com os méritos do sistema de esgoto da Freetown, aparentemente implementado pelos primeiros “colonizadores" nos anos de 1970 e 1980, agora utilizando tratamento do tipo reed-bed, e a suposta inveja de Copenhagen: Quem precisou das autoridades e de seus planejamentos? Cyboli ponderou sobre a relevância do paradigma

\footnotetext{
13 Um ponto seguramente destacado pela cruel farsa da COP15 em 2009.

14 Moradores de Christiania de várias maneiras se referem em língua inglesa como "cristianitas", "cristianianos" ou “cristãos”, ignorando a conotação religiosa da última referência.
} 
de urbanismo sustentável para Christiania, e vice-versa. Tendo surgido nos anos de 1960 e 1970, o urbanismo sustentável podia ser visto como uma resposta a ambos: o dano ecológico causado pela rápida industrialização e a deterioração generalizada na qualidade da vida urbana e ambientes, fruto de uma similar urbanização acelerada (WHITEHEAD, 2011). Praticamente sinônimo dos paradigmas de planejamento do "novo urbanismo" e do "crescimento otimizado", o urbanismo sustentável é caracterizado pela utilização dos sistemas urbanos existentes, além de fortemente associado com um empoderamento da comunidade (GIRARDET, 1999, GIRARDET, 2004, WHITEHEAD, 2007). Além desta inclusão, alguns elementos comuns ao urbanismo sustentável são: planejamento espacial baseado em vias para caminhadas, em lugar de ruas para carros; arquitetura e edificações em maior harmonia com a natureza (BLASSINGAME, 1998; GUY; MOORE, 2007; WINES, 2000); um compromisso moral com a justiça; a equidade intra e intergeracional destacada pela Brundtland Commission (WCED, 1987). Graham Houghton enumera cinco princípios centrais de equidade para o desenvolvimento sustentável e, por conseguinte, para o urbanismo sustentável: "equidade intergeracional e intrageracional, responsabilidade além-fronteiras (de maneira que os custos ambientais não se transfiram para além das fronteiras), equidade entre espécies e equidade de procedimentos" (SATTERTHWAITE, 1999, p. 10).

O urbanismo sustentável enxerga a cidade não como a raiz de todos os males sociais e ecológicos, mas como o caminho necessário para o desenvolvimento sustentável: "a forma e a qualidade das relações urbanas ambientais, econômicas e sociais definirão cada vez mais a forma e a qualidade da própria vida humana" (WHITEHEAD, 2009, p. 109). Ao buscar um estabelecimento vantajoso entre o desenvolvimento econômico, a justiça social e a proteção ambiental, o urbanismo sustentável acaba por exibir características marcadamente utópicas. Além do mais, responsabilizar-se pelos impactos ambientais, sociais e econômicos no espaço e no tempo assinala a cidade sustentável como relacional, uma parte da ecotopia, em lugar de ser uma Ecópolis isolada, elitista e contraditória ${ }^{15}$. A densificação e intensificação são cada

\footnotetext{
${ }^{15}$ Observo aqui os projetos reais e imaginados de Masdar, nos Emirados Árabes Unidos, e de Dongtan, na China, respectivamente. Disponível em <http://www.masdarcity.ae/en/> e também em $<$ http://www.arup.com/_assets/_download/8CFDEE1A-CC3E-EA1A-25FD80B2315B50FD.pdf〉. Vários acessos.
} 
vez mais vistas como virtudes urbanas, com alguns autores voltando-se para favelas, tais como Dharavi, em Mumbai, tendo em vista modelos de comunidade, indústria localizada e reciclagem (PEARCE, 2006; MCCLOUD, 2010). Urbanismo sustentável também é reconhecer que as cidades se diferenciam e que não há soluções tecnológicas coringas (WHITEHEAD, 2009). Porém, para muitos ativistas, a "boa administração" está sempre no centro das formulações do urbanismo sustentável. Evans et al. destacam a “administração" como conceito-chave, embora definindo-a como a interação entre governo e governança nos campos das províncias de autoridades locais e sociedade civil, respectivamente (EVANS et al., 2005).

Ao escrever um obituário para a cidade sustentável como uma provocação, Mark Whitehead afirma que o compromisso retórico de muitas cidades com o desenvolvimento sustentável aparece em total contraste com as práticas direcionadas ao crescimento econômico, o qual sempre ultrapassa em importância as considerações sociais e ambientais (WHITEHEAD, 2011). Ele cita Erik Swyngedouw, que vai tão longe a ponto de sugerir que o urbanismo sustentável está exacerbando as mazelas do desenvolvimento urbano neoliberal desenfreado, além de atenuar as abordagens radicais (SWYNGEDOUW, 2010). Em vocabulário situacionista, o urbanismo sustentável sofreu recuperação, a cidade sustentável foi mercadorizada (DEBORD, 1983). Assim, considerando os prós e os contras de mover-se para além do paradigma do urbanismo sustentável, Whitehead propõe que a ameaça emana de três doutrinas: o hiper-liberalismo, o neolocalismo e o pragmatismo municipal. Ele estuda Mesa, no Arizona, em termos de hiper-liberalismo, concluindo que "a saída para a recessão urbana é precisamente a que posiciona a expansão econômica à frente das potenciais consequências ambientais" (WHITEHEAD, 2011). Totnes, em Devon, é utilizado como um exemplo de neolocalização, com a conclusão de Whitehead de que o urbanismo das iniciativas da Cidade de Transição intrinsecamente carece da ambição utópica do urbanismo sustentável: a resiliência substitui o desenvolvimento sustentável como o viés central de um movimento milenar que prepara para o pior, isto é, o pico do uso do petróleo [peak oil] e a mudança climática (MASON; WHITEHEAD, 2012b). O Meridian Gap, em West Midlands, constitui o exemplo de Whitehead do pragmatismo municipal, o qual se manifesta em compensações entre os 
objetivos econômicos, sociais e ambientais do desenvolvimento sustentável, tacitamente reconhecendo a impossibilidade utópica do ganha-ganha-ganha.

\section{Urbanismo unitário e a Nova Babilônia}

Cyboli foi em direção ao bar Månefiskeren para tomar um café e assistir à desativação simbólica de uma das frequentes patrulhas policiais impostas pelas autoridades dinamarquesas. Cada patrulha foi aclamada com música reggae retumbante pró-cannabis, com faixas como Legalise it, de Peter Tosh, quando foi registrado, no placar externo ao bar, por uma equipe diligente: "Não vamos deixar que os imbecis nos destruam", conforme disseram a Cyboli. Se o urbanismo informa o urbano como espacialmente distinto, então o urbanismo crítico possui, em seu núcleo, uma preocupação com os efeitos deletérios associados à urbanização, sob a lógica da modernidade capitalista. Desse modo, os urbanismos ambientais poderiam se concentrar na exploração não apenas das pessoas urbanas, mas de uma natureza mais ampla no interior - e para o provisionamento - de áreas urbanas. O urbanismo modernista substitui a possibilidade de um espaço ecológico transformativo com uma pseudo natureza: vários itens verdes mensurados, geridos e cuidados. Constant Nieuwenhuys, o artista holandês que se tornou um arquiteto situacionista, rejeitou esta ideia modernista de "cidade verde" como elitista, defendendo a conquista da natureza, em lugar de requerer uma falsa unidade restrita a lugares determinados, como os parques ${ }^{16}$.

Constant declara que "A cidade produziu as massas, somente as massas podem dar forma à cidade" (apud MCDONOUGH, 2009, p. 115): "uma poesia feita por todos"17" (SADLER, 1999, p. 134). No entanto, as vidas das massas foram dominadas pelo capitalismo, de forma que elas foram inibidas de dar forma à cidade, para além de reproduzi-la prosaicamente. Se o urbanismo unitário dos situacionistas significava mover-

\footnotetext{
${ }^{16}$ Observo que o (um) domínio da natureza, para além de estar associada com o pensamento iluminista e Francis Bacon, é, em termos de realização espacial muito europeia. Além disso, a concepção de Constant está seguramente repleta de ironia enquanto crítica.

${ }^{17}$ Sadler afirma que este refrão situacionista-chave foi herdado do escritor novecentista Isidore Ducasse. [N. do T.: Isidore Lucien Ducasse (1846-1870) ou, como era também conhecido, Conde de Lautréamont, foi considerado pelos situacionistas o precursor do surrealismo e da estratégia do détournement.]
} 
se para além do abstrato, atingindo o concreto, então precisou abranger um paradoxo, o qual, parece, foi o que Constant tentou com seu projeto da Nova Babilônia. A prática inicial do urbanismo unitário teve de dar espaço para uma cidade que, por um lado, poderia ser um lugar criativo para a moradia das massas, e ao mesmo tempo servir para a produção daquelas mesmas massas como novos seres criativos; a arquitetura da Nova Babilônia teve de inspirar a transgressão via formatação consciente de situações. Constant concebeu sua cidade como predominantemente um espaço social com paredes móveis a serem reconfiguradas pelos moradores, da forma que quisessem. Sadler aponta que os situacionistas concordavam que: "a criação da cidade situacionista passaria do lugar dos pais da cidade vanguarda para seus cidadãos" (SADLER, 1999, p. 120): “Constant nunca deixou de reiterar que, em última instância, a Nova Babilônia poderia somente ser um projeto social coletivo, e que seu trabalho deveria ser entendido como sendo nada mais do que uma estrutura projetada para a construção de situações" (SADLER, 1999, p. 222). Procurando se desviar de qualquer carga de vanguardismo, Constant apresenta a Nova Babilônia na qualidade de:

Um projeto imaginário; ele antecipa a história, um projeto futurístico; baseia-se em um desejável curso histórico e, portanto, em um certo sentido constitui um projeto utópico. Todavia, prefiro chamá-lo de projeto realista porque este se distancia da condição atual, que já perdeu o contato com a realidade, e porque se funda no que é tecnicamente exequível, no que é desejável do ponto de vista humano, no que é inevitável do ponto de vista social (MCDONOUGH, 2009, p. 116).

Simon Sadler ressalta a dívida do urbanismo unitário com a "arquitetura unitária" do "sociólogo utópico" Charles Fourier: "Assim como a arquitetura unitária de Fourier, o urbanismo unitário situacionista foi uma visão da unificação do espaço e da arquitetura com o corpo social, bem como com o corpo do indivíduo também" (SADLER, 1999, p. 118). O urbanismo unitário é a refutação da visão modernista, exemplificada pelos situacionistas por Le Corbusier; a vida “em participação afinada com o processo de produção" (MCDONOUGH, 2009, p. 114). Para Constant, no coração do urbanismo unitário jaz 
a função abrangente da vida: a criatividade, o impulso por manifestar-se, para tornar a vida em um evento único, para realizar a vida como tal. 0 urbanismo não é um projeto industrial, a cidade não é um objeto funcional, esteticamente 'são' ou algo assim; a cidade é uma paisagem artificial construída por seres humanos na qual a aventura da vida se desdobra (MCDONOUGH, 2009, p. 114).

A visão situacionista da natureza, ao menos na forma representada por Constant na Nova Babilônia, pode ser difícil de entender a partir de uma perspectiva ambientalista contemporânea. Um pouco de geografia histórica pode esclarecer. Segundo Constant, em 1960, o urbanismo unitário era concebido em uma sociedade que se percebia totalmente em um contexto de recursos naturais infinitos. O futuro seria, consequentemente, aquele percorrido por viagens ilimitadas, especialmente de carro e avião. Desse modo, Constant apresenta uma visão modernista radical da natureza conforme "representada; matéria-prima controlada por seres humanos e utilizadas de acordo com suas necessidades" (MCDONOUGH, 2009, p. 117). A natureza se transforma em cultura e é substituída pela tecnologia. O crescimento populacional e a urbanização, Constant acreditava, significaria que "a cidade poderia, ao fim, expandir-se para cobrir toda a superfície da terra", mas também que esta superfície teria de ser utilizada mais intensivamente (MCDONOUGH, 2009, p. 117): “para o transporte motorizado e a agricultura, a natureza selvagem e os monumentos históricos” (SADLER, 1999, p. 129). Nova Babilônia estaria baseada "em uma separação rígida entre o tráfego e o espaço industrial, por um lado, e o espaço social e residencial, por outro" (MCDONOUGH, 2009, p. 120). A cidade seria implementada e apoiada em pilotis ${ }^{18}$; as fábricas seriam construídas abaixo do solo' ${ }^{19}$; o tráfego fluiria livremente na superfície da terra. Em essência, esta sobrecidade seria artificialmente iluminada e ventilada. Constant abraçou a última tecnologia estrutural, e sua arquitetura foi, na tradição utópica, fantástica, flutuante, suspensa, inspiradora, em lugar de prescritiva; ela exigiu materiais leves e de alta tecnologia, dotados de propriedades de engenharia de ponta. De maneira fascinante,

\footnotetext{
${ }^{18}$ Uma série de colunas de apoio.

${ }^{19}$ Note a ressonância com Metropolis de Fritz Lang.
} 
Constant construiu suas maquetes, seus primeiros modelos, a partir do lixo industrial. Por exemplo, ao reciclar os para-brisas de um carro-bolha ${ }^{20}$ para sua Sala de Concertos de Música Eletrônica.

Constant identifica o urbanismo modernista em seu papel altamente decisivo na cultura, mas em um sentido negativo, uma vez que se preocupa especialmente com tecnologias superficiais de gerenciamento de tráfego e de moradia, que fetichizam particularmente as geografias do carro particular, contando-se, ao fim, o princípio fundamental de uma produção eficiente. Considerando-o um desastre, Constant enxerga no urbanismo modernista uma ameaça à própria existência da cultura, uma ameaça específica a espaços sociais nos quais "uma nova cultura poderia surgir". Ele analisa que há aspectos interligados do urbanismo unitário, porém distintos: (i) uma transformação de nossos hábitos, nosso estilo de vida e (ii) uma mudança profunda em como nosso ambiente é produzido. O urbanismo unitário está fundado na ideia de impulsionar vidas criativas, sendo este, na definição de Constant:

uma deliberada intervenção na práxis da vida diária e no ambiente diário; uma intervenção dirigida para proporcionar harmonia duradoura em nossas vidas, em meio a nossas reais necessidades e novas possibilidades que surgirão, e que, por sua vez, transformarão estas necessidades...trata-se da objetivização do impulso criativo, da coletivização das obras de arte, a materialização de um estilo de vida dinâmico (MCDONOUGH, 2009, p. 115).

\section{A materialidade das utopias e ecotopias literais e literárias}

\section{Fatos concretos da ficção}

Fazendo o caminho de volta a Den Blå Karamel, a casa de madeira em que estava hospedado com amigos, Cyboli pegou a trilha escura de madeira, ao longo de um curso d’água, através da área construída como uma defesa contra a invasão sueca, em fins do século XVII. Fortuitamente, os séculos XVI e XVII também produziram um número de textos utópicos, cuja influência sobreviveu às intempéries do tempo, não só pelas

\footnotetext{
${ }^{20}$ Um termo genérico para designar carros pequenos, econômicos e geralmente de três rodas dos anos de 1960, especialmente aqueles produzidos pela BMW e pela Messerschmitt.
} 
sistemáticas contestações de seus significados verdadeiros. Aqui, estamos interessados no que sobrevive às intempéries do espaço, especialmente no que se refere à materialidade da ambiência. A Utopia de Thomas More (MORE, 2008) foi obra precursora de A cidade do sol, de Tommaso Campanella (CAMPANELLA, 1981), da Nova Atlântida, de Francis Bacon (BACON, 2008), bem como de A llha dos pinheiros, de Henry Neville (NEVILLE, 2008). A materialidade da Utopia de More prefigura uma aspiração modernista quase extraordinária do ambiente construído, ou no mínimo reflete uma inércia extraordinária na tecnologia dominante de materiais de construção. Depreciando as “cabanas familiares", feitas com madeira bruta, paredes de taipa, palha e sapê e vistas como "pobres", "deficientes" e pertencentes ao passado, More descreve a materialidade de Amaurote, a capital de Utopia:

\begin{abstract}
As ruas estão dispostas e estabelecidas bela e comodamente, funcionando para carregamentos, e também contra os ventos. As casas são formosas e maravilhosas edificações, sendo que, do lado da rua, estão dispostas juntas e longamente alinhadas por toda sua extensão, sem qualquer partição ou separação. As ruas têm seis metros de largura. $\mathrm{Na}$ parte anterior das casas, através de todo o comprimento da rua, jazem os grandes jardins... as casas são curiosamente construídas em um modelo belo e galante, com três andares. As partes externas das paredes são feitas de pedra, reboco ou tijolo, enquanto as partes internas são reforçadas com trabalho em madeira. Os tetos são planos e chatos, revestidos com certo tipo de argamassa sem custo, e ainda temperada de maneira que o fogo não os danifique ou os destrua. Além disso, resiste à violência do tempo de melhor modo que qualquer fragmento de chumbo. Eles mantêm o vento distante das janelas com vidro, uma vez que aqui é muito utilizado. Também em algum lugar com fino tecido de linho mergulhado em óleo ou âmbar; tudo isso para duas comodidades, pois assim o ambiente fica mais iluminado e o vento se mantém distante (MORE, 2008, p. 54-55).
\end{abstract}

Analogamente, os moradores da Nova Atlântida de Bacon vivem em casas de tijolos com janelas de vidro. Ambos os autores equacionam a entrada de luz nas moradias com o progresso. Enquanto More imagina uma argamassa que funciona como o cimento portland comum (ordinary portland cement - OPC) ${ }^{21}$, embora fundamentalmente

\footnotetext{
${ }^{21}$ Alguns comentadores consideram que esta noção de More foi mormente inspirada pela tecnologia cerâmica.
} 
A sustentabilidade encontra a teoria situacionista na cidade: um relato de détournement e a retomada de uma Ecotopia justa e rebelde

Kelvin Mason

diferente por ser "sem custo", os “Aposentos da Saúde” de Bacon poderiam ser entendidas como as primeiras noções de qualidade de ar interna (indoor air quality - IAQ), especialmente na forma como a arquitetura sustentável contemporânea enxerga os cada vez mais numerosos projetos à prova de correntes de ar, tais como o Passivhaus. De outro lado, o protagonista patriarca de $A$ llha dos pinheiros rapidamente cria uma cabine de pedaços de madeira bruta, montada com tábuas recuperadas de seu acidente marítimo e revestidas com panos de velas esticadas, antes de seriamente criar o que Susan Bruce cunha de "pornotopia” - um lugar "onde taludes musgosos e árvores fornecem todo o abrigo que alguém precisa" (BRUCE, 2008, p. xxxix).

Figura 2 - Parte anterior de Bananhuset

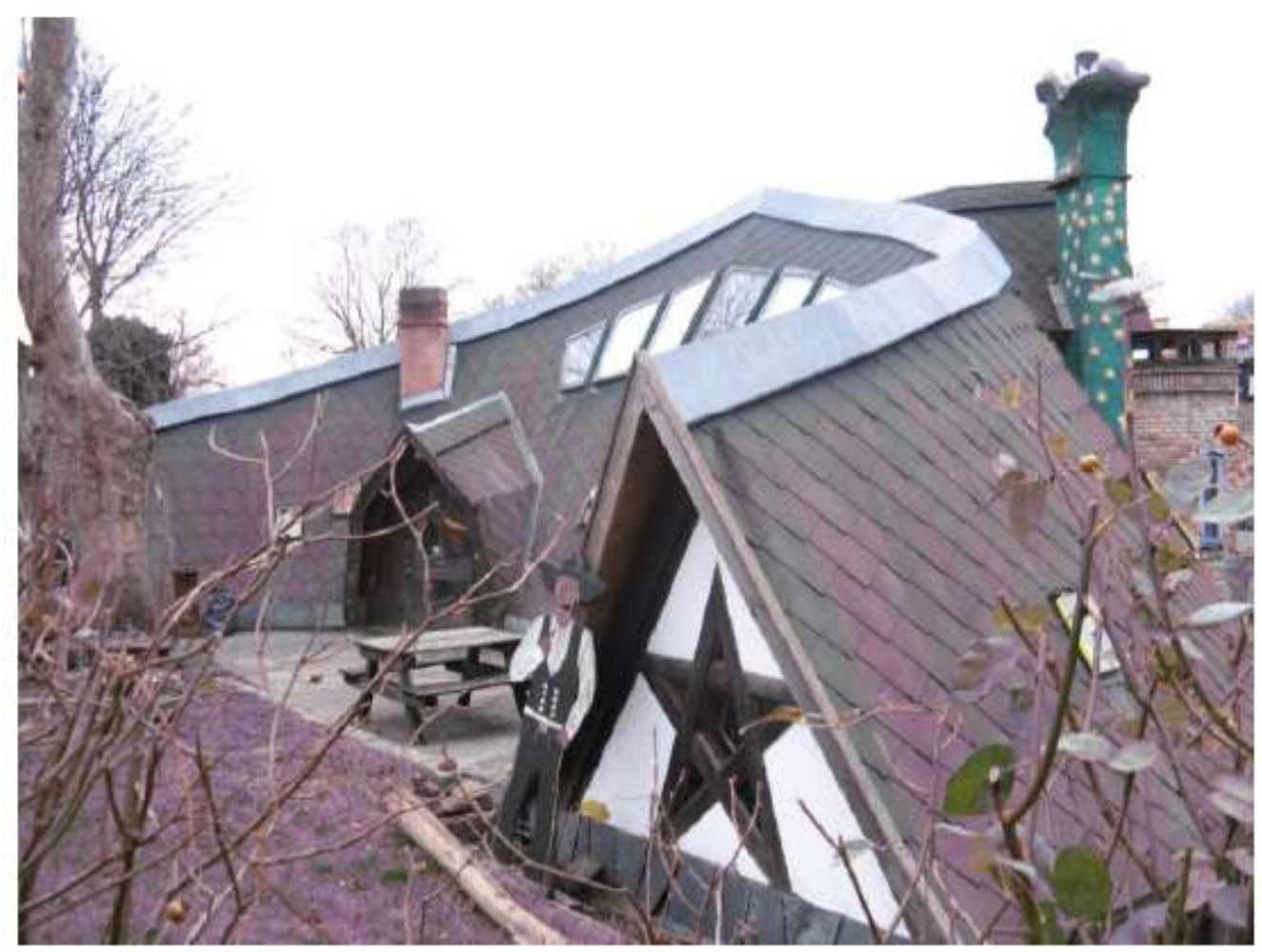

Foto: Kelvin Mason.

Passando pela Bananhuset ${ }^{22}$ (Figura 2), Cyboli sorriu para a sua arquitetura lúdica, seu cowboy estranho montando guarda. Tommaso Campanella, um dominicano, estava

\footnotetext{
${ }^{22}$ Bananhuset, a Casa de Banana, foi construída por “naverne”, servindo como clube do Norte da Europa
} 
cumprindo uma sentença de prisão de 27 anos, referente a uma conspiração contra o domínio de Nápoles pelos espanhóis, quando escrevia A cidade do sol (Civitas solis). Malcolm Miles escreve sobre a relação entre a arquitetura de Civitas Solis e o conhecimento de sua sociedade:

A cidade, descreve Campanella, é radial, dividida em sete anéis... Cada circuito de paredes contém em ambas as faces, interna e externa, um subconjunto de conhecimento estabelecido: primeiro, figuras matemáticas e a Terra; segundo, minerais e geografias; terceiro, flora e peixes; quarto, pássaros e feras rastejantes; quinto, animais em ambos os lados; sexto, artes mecânicas e seus instrumentos... Então, a cidade solar difere novamente de uma transposição para um espaço geométrico de uma ordem monástica, pelo que o conhecimento é divulgado, e não trancado em uma comunidade acadêmica, a qual guarda seus textos latinos, assim salvaguardando sua interpretação; cada geração da população da cidade é levada ao redor do circuito de murais para fins educativos (MILES, 2005, p. 17).

Um conhecimento da sociedade sendo constitutivo do espaço público e sempre aberto à sua interpretação certamente tem um apelo epistemológico transgressor. Cyboli pensava as paredes, elas mesmas, como portadoras de conhecimento: quão significativa era a sua materialidade; assim como os textos escritos, elas poderiam significar muito para o conhecimento de uma sociedade? O que poderia ser interpretado a partir das tais paredes feitas de, digamos, concreto em aço reforçado, comparadas com paredes de fardos de palha e com argamassa de calcário e cânhamo? Estas perguntas têm um significado especial para a ecotopia: se uma parede de Civitas solis fosse dedicada ao conhecimento de sustentabilidade ambiental, o material de que é feito (e realmente como teria sido construída, quanto de trabalho teria sido empregado) seria de profunda importância.

Primeiramente publicado em 1975, a mais notável ocorrência de uma ecotopia contemporânea é o romance epônimo de Ernest Callenbach (CALLENBACH, 1975).

para estes artífices de construtores. Conforme muitas casas construídas pela comunidade em Christiania, ao contrário daquelas que foram reformadas, Bananhuset é construída principalmente a partir de materiais que foram regenerados a baixo ou nenhum custo. A madeira é o principal material utilizado em Bananhuset. 
Ecotopia é uma Califórnia ecologicamente transformada, que conquistou uma atribulada independência de Estados Unidos ambientalmente desastrosos (CALLENBACH, 2004). Na Ecotopia, embora Callenbach flerte com a noção de moradia de massa construída com encanamento extrudido feito de plástico derivado de algodão, o material de construção predominante é a madeira, com a qual ecotopianos têm uma relação espiritual, quase equiparável à adoração de árvores:

Outro dia para ver alguns carpinteiros trabalhando em um edifício. Marcavam e serravam a madeira amavelmente (usando a própria força muscular, nenhuma serra). Os padrões de pregos, percebi, eram belamente dispostos, e o ritmo das batidas do martelo pareciam pacientes, um tanto calmas. Quando erguiam peças de madeira, carregavam-nas cuidadosamente, encaixavam-nas (produzem muitas juntas ao entalhá-las e ao pregá-las). Pareciam quase colaborar com a madeira, em lugar de forçá-la à forma do edifício (CALLENBACH, 1975, p. 47).

Callenbach mais tarde "informa” que esta relação empática com a madeira é estimulada por pessoas obrigadas ao trabalho de silvicultura antes que pudessem comprar a madeira para construir uma casa, auxiliando a gerenciar os terrenos na floresta de maneira sustentável, replantando para repor a madeira que irão utilizar. É uma política da Ecotopia "que todos os edifícios sejam de materiais renováveis e biodegradáveis" (CALLENBACH, 1975, p. 97). Os ecotopianos de Callenbach também herdaram o ambiente construído e os materiais do capitalismo, mas eles realizam escolhas sobre suas utilidades, escolhas que impressionam o jornalista narrador de Callenbach, William Weston:

os grandes arranha-céus da cidade, outrora sedes de empresas vastas, tornaram-se apartamentos!... Milhares de casas baratas em bairros mais novos (negativamente rotuladas de caixas "ticky-tacky" pelos meus informantes) perderam sua fiação, estrutura de vidro e ferragens, além de demolidas (CALLENBACH, 1975, p. 13-14). 
Uma característica predominante da Ecotopia é a de ser um ambiente de construção que vai para além dos usos de automóveis. Na "Cidade Soul”, a área negra da Ecotopia segregada voluntariamente, "arquitetos criados em guetos têm sido líderes proponentes da reconstrução das cidades ecotópicas baseadas em princípios mais humanos que automobilísticos" (CALLENBACH, 1975, p. 99).

\section{Christiania: Freetown (Fristad), Free Haven (Frihavn)}

Atrás das nuvens de fumaça, olhares suspeitos e carícias fugazes, a Free Haven, Christiania ainda está tomando forma... organizações alternativas sem liderança, o único senso de comunidade e a aceitação da humanidade em todas as suas formas (LAURISTEN, 2002, p. 8).

É bem irônico que o título "Free Haven" de Christiania venha de uma tradução literal de sua geografia na Frihavn (porto livre), área de Copenhagen - uma designação que foi originalmente comercial, não denotando nenhuma taxa alfandegária. Na mesma veia irônica, dada a orgulhosa e autoproclamada "arquitetura sem arquitetos" de Christiania, um vizinho próximo é a Royal Danish School of Architecture. Fornecendo guarida para aproximadamente mil pessoas, sobretudo emigrados e refugiados do estado dinamarquês, Christiania dá boas vindas a seus visitantes com a placa: "Agora você está saindo da União Europeia”. Incluindo-se a área de fortificações - muralhas construídas para repelir a invasão sueca, Christiania encampa mais de 85 acres do que certamente seria um bem imobiliário de Copenhagen (Figura 3). O centro - ou as "bolas"23 - do terreno (Figura 1) teria sido um quartel general e um arsenal. Grupos variados invadiram e começaram a ocupar o complexo abandonado a inícios dos anos de 1970, especialmente um movimento de pessoas sem-teto e ambientalistas ou hippies buscando um lugar para praticar a ecotopia. Dentre as muitas e sistemáticas lutas políticas, Christiania estabeleceu um pacto com o estado dinamarquês sobre alguns dos

\footnotetext{
23 Alguns domiciliados comparam o mapa de Christiania com um falo, sendo a área mais habitada representada como a bolsa escrotal.
} 
serviços, sobretudo a distribuição de energia elétrica ${ }^{24}$, e a Free Haven se proclama uma comunidade autônoma. É autogestionada com as discussões e debates sobre os espaços públicos e privados cotidianos mediados em uma rede de reuniões: House Meetings (Reuniões de Moradia) para os domiciliados com moradias compartilhadas; Area Meetings (Reuniões de Área) para as quinze áreas geográficas designadas de Christiania, para lidar com assuntos locais; Specialist Treasurer's Meetings (Reuniões do Tesouro), Economy (Reuniões de Economia), Business (Reuniões de Negócios) e Building (Reuniões de Construção); além do The Common Meeting (Reunião dos Comuns), o fórum de última instância, constituído com base em princípios participativos, que arbitra sobre questões de litígio, informa as "negociações" em conjunto com o governo dinamarquês e funciona como um poder judiciário. As casas não podem ser controladas, herdadas ou de outra forma repassadas, e a posse deve ser decidida pelo Area Meetings em primeira instância. Christiania gerencia sua própria economia, recolhe as rendas ${ }^{25}$ e administra um "fundo comum" (tesouro). Sem automóveis, ao produzir seus próprios modelos de bicicletas, ao fabricar fogões a lenha, ao usar uma tecnologia de tratamento de esgoto natural, de compostagem e também de reciclagem, Christiania se identifica como "os pulmões verdes de Copenhagen".

\footnotetext{
24 Uma acomodação desprezada por um de meus informantes por haver retardado o próprio desenvolvimento dos sistemas renováveis de energia de Christiania.

${ }^{25}$ Como fazer cumprir o pagamento daqueles que se recusam a pagar é um verdadeiro ponto de discórdia, e às vezes o déficit no orçamento ameaça desgastar os serviços, tais como manutenção predial e jardinagem.
} 
A sustentabilidade encontra a teoria situacionista na cidade: um relato de détournement e a retomada de uma Ecotopia justa e rebelde

Kelvin Mason

Figura 3 - Moradia ribeirinha em Christiania

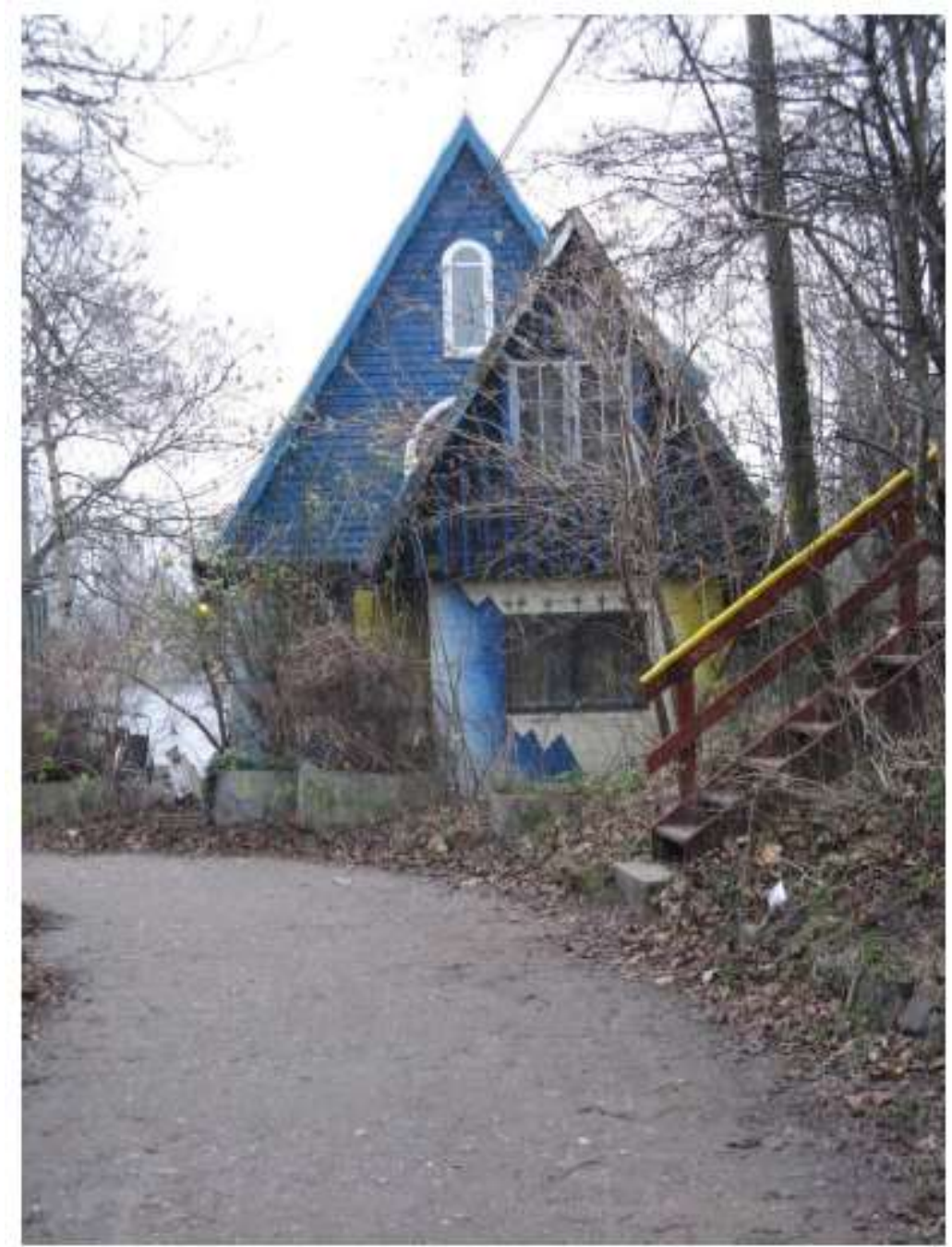

Cyboli vê em Christiania um lugar que o faz formigar - de prazer, expectativa, suavidade e um toque de medo... Estar aqui o faz sentir-se muito vivo. As trilhas de Christiania serpenteiam e se atravessam, as direções são incertas, não há placas. À noite, longe do centro nomádico, fervoroso, fulgurante, cintilante, festeiro, há silêncio, escuridão - não há luzes nas ruas -, estrelas; é frequente perder-se, achar-se. Do cheiro fumacento dos bares, através da brisa refrescante que passa sobre a água, para o aroma madeireiro das casas... As construções variavam da alvenaria sombria dos antigos quartéis generais - embora muitas vezes alegrada e empoderada pelo vibrante grafite da resistência, nas mais variadas construções de madeira erguidas pelos cristianitas ao longo das décadas, em forma de barracas e navios, casas construídas a partir de sucatas, belas e 
por vezes parecendo estruturalmente impossíveis, residências construídas na água ou escondidas nas florestas (até a lúdica e tecnologicamente sofisticada Bananhuset). A despeito de décadas de desenvolvimento, aspectos da vida cotidiana em Christiania permanecem rústicos e prontos para muitos. A pobreza econômica no "paraíso dos perdidos" é a norma, e a busca de comida no lixo é tanto uma necessidade quanto o é o freeganismo ideológico. Muitas casas são frias e atravessadas por correntes de ar, segundo os padrões modernos, frequentemente aquecidas somente com um fogão a lenha. Alguns lugares na floresta dispõem de apenas um banheiro externo, uma caminhada inconveniente em todos os climas. Mas, para Cyboli, as sensações menos prazerosas também marcaram sua própria vitalidade - faziam parte da vida - e também o compeliriam para a ação, ao menos para conseguir lenha ou certificar-se de que o vaso sanitário estava limpo e armazenado com serragem. Para moradores permanentes, a escolha era deles se deveriam depositar as energias em revisões de projetos ou em saneamento interno (ou, em vez de tudo isso, compor música e divertir-se em um pouco de primitivismo). E as compensações eram agradáveis, por exemplo, uma visita à sauna pública em um novembro frio mais do que resolveu o problema da falta de um chuveiro doméstico: uma cerveja e uma conversa fora de Inkøbcentralen, a loja comunitária, depois... Havia ações políticas frequentes de vários grupos também, levando Christiania para uma Dinamarca mais larga, para um mundo mais largo: criticando, engajando-se. Havia uma tradição iniciada pelas famosas incursões do grupo de teatro ativista Solvognen, por exemplo, vestindo-se de Papai Noel no Natal e distribuindo mercadorias de lojas de departamento, ou participar de celebrações corporativas do Dia da Independência Americana como americanos nativos montados em cavalos.

\section{Discussão (gato escaldado tem medo de água fria: O Provocador)}

Comecemos pelo seu louvor a Christiania, disse O Provocador, zumbindo irritantemente em torno da cabeça de Cyboli, enquanto ele se sentava no Den Blå Karamel quando tentava escrever. Você apresenta o espaço da propalada Freetown como dinâmico, parecendo utilizar as representações do espaço de Lefebvre em direção 
ao espaço representacional, ao menos investindo em um equilíbrio entre os espaços dialeticamente conectados que, suponho, você os veria distorcidos na maior parte do mundo, para além das "fronteiras" de Christiania?

Cyboli respondeu: Realmente vejo uma Christiania repleta de paixão política, inflamada, em lugar de tomada pelos interesses agressivos do estado. Uma tática central da campanha do estado contra a Freetown é a de primeiramente forçar que as pessoas se registrem como domiciliadas que têm bens de propriedade, para, assim, "encorajar" a propriedade privada, tentando estimular o poder aquisitivo de alguns domiciliados que se esforçaram muito nas melhorias de suas casas. É como se o estado compreendesse muito bem a teoria de Lefebvre, a temesse, e ativamente a empregasse para negar a ameaça de um bom exemplo. Christiania está cheia de imaginações fantásticas e a comunidade sempre soube a respeito da criação de situações. Conforme diz Lefebvre: "os momentos de 'presença' no cotidiano jazem naqueles cuja autenticidade é desalienadora, em meio às distrações e às relações mercantilizadas da modernidade, além de naqueles que passam e que podem revelar um leque de possibilidades" (PINDER, 2005b, p. 166). Tal conhecimento da comunidade é mediado por práticas espaciais, incluindo-se a materialidade do lugar, a qual rompe com as representações capitalistas do espaço que o estado busca sistematicamente impor. E esse rompimento de fato revela um leque de possibilidades: um potencial político. O mesmo vale para as outras arquiteturas urbanas que são conscientemente políticas: as tendas do Camp for climate action próximo ao aeroporto Heathrow, em 2007, e no bairro financeiro de Londres durante a reunião do G20 em 2009; tendas que são visivelmente vulneráveis, mas que também mascaram ${ }^{26}$. 0 simbolismo do longo acampamento de quase uma década de Brian Haw na parte externa do "Palácio de Westminster", uma ação contra as guerras do Reino Unido no Iraque e no Afeganistão, uma incursão espacial - uma situação - tão intolerável para a elite dominante que chegaram ao ponto de alterar a lei para acabar com esta ${ }^{27}$. Entretanto, 0 bloqueio do protesto de Haw revelou ainda mais possibilidades políticas do que o ato do

\footnotetext{
${ }^{26}$ De maneira similar, os acampamentos do movimento Occupy em mais de 900 cidades em fins de 2011.

27 A Lei de Polícia e de Crime Altamente Organizado de 2005 introduziu restrições explicitamente em protestos nos arredores do Palácio de Westminster, o que também ensejou a criação de um Esquadrão de Crime Altamente Organizado, fornecendo à polícia maiores poderes de voz de prisão. O protesto de Brian Haw foi recriado pelo artista Mark Wallinger, o qual havia sido indicado para o Turner Prize.
} 
acampamento em si. Se aqui houvesse espaço para tal, poderia continuar com exemplos, tais como o movimento Reclaim the $\operatorname{Streets}^{28}$, o qual se inspira tanto no urbanismo unitário como no urbanismo sustentável, uma visão do carro como uma tecnologia central da sociedade do espetáculo. Ou poderia me referir à criação de situações do movimento Occupy, momentos prolongados de presença...

Obviamente, estas ações são utópicas e essencialmente urbanas, disse $\mathrm{O}$ Provocador. Elas evidentemente transcendem seu simbolismo e marginalidade: são realistas, autênticas, críticas, em lugar de compensatórias e empoderadas. As massas poderão aprender sobre tais ações de vanguarda, seja na escala de Christiania ou na arte individual de banners, bandeiras e barricadas de Brian Haw. Estas, claramente, não são abstrações da vida cotidiana. Whitehead aponta que, "Adotar mais interpretações radicais de desenvolvimento urbano sustentável poderia ajudar a construir uma cultura de planejamento urbano mais progressista" (WHITEHEAD, 2011). Na verdade, seu urbanismo unitário sustentável é certamente mais radical: perturbar os espaços da cidade só poderá imediatamente inspirar que as pessoas reciclem e pedalem para trabalhar. A Nova Babilônia é a Ecópolis! Uma cidade espacialmente construída por brincalhões e vencidos está claramente indo para um lugar altivo: a justiça está bem servida com a criação de situações...

\section{Conclusão: urbanismo unitário sustentável?}

Tendo sido atacado pela ironia socrática, o que pareceu uma eternidade, e embora seus argumentos tenham continuamente sido reduzidos ao absurdo, o Capitão Cyboli sobreviveu para arquivar este relatório de campo:

Minha pesquisa debruçou-se sobre a questão de como a materialidade do ambiente urbano construído pode, ao mesmo tempo, refletir e produzir desenvolvimento sustentável, uma questão inspirada em A cidade do sol de Campanella. De posse disto, concentrei-me no obituário para a cidade sustentável de Mark Whitehead, tomando-o

\footnotetext{
${ }^{28}$ Reclaim the Streets: "Uma rede de ação direta para revoluções em escala local, global e socioecológica de forma a transcender as sociedades autoritárias e hierárquicas (inclusive o capitalismo), e ainda estar em casa para o chá". Disponível em <http://rts.gn.apc.org/sortit.htm>. Vários acessos.
} 
como a provocação pretendida. No contexto de seu utopismo compartilhado, comparei a cidade sustentável e o urbanismo sustentável com a Nova Babilônia, bem como com o urbanismo unitário. Embora sua visão da natureza seja muito datada e sua relação com a sustentabilidade altamente problemática, a criação de situações da Nova Babilônia continua a inspirar. Empiricamente, vaguei pelas utopias literárias e exemplos do que poderia ser concreto, concentrando-me em Christiania como uma manifestação do último. Não me detive nos elementos distópicos de Christiania - por exemplo, a presença malévola de facções de traficantes na comunidade -, tampouco examinei a relação entre estes elementos distópicos e a inevitável incompletude da Christiania utópica, devido à sistemática intervenção do estado dinamarquês. Além do que, Christiania não é apresentada como um integral modelo transferível da nova cidade sustentável. De saída diz-se que as características fundamentais da cidade sustentável vislumbrada pelo capitalismo serão a diferença, a diversidade e a unicidade local.

Recorri à teoria da produção do espaço de Lefebvre para analisar a mediação do espaço representacional e as representações do espaço pelas práticas sociais: meu interesse aqui é no potencial transgressor do protesto e da arquitetura citadina para quebrar a concepção da sociedade do espetáculo e servir para produzir espaços de possibilidades políticas ampliadas. Defendo que o ressurgimento do urbanismo sustentável significará abraçar a radicalidade desde a esfera da administração ou governança até a participação do cidadão. Em termos imediatos, significará os cidadãos tomando providências coletivas e criativas para conter as doutrinas negadoras identificadas por Whitehead: o hiper-liberalismo, o neo-localismo e o pragmatismo municipal. Tais medidas deveriam almejar a criação de situações através do détournement da expressão objetiva de representações do espaço para ressaltar as vítimas da cidade sustentável recuperada, i. e., tanto o gerenciamento do ambiente natural quanto a justiça social. Enquanto este détournement deve ser radical ${ }^{29}$, lanço mão de Stuart Hodkinson para também evocar um pragmatismo estratégico: não entendo por que, por exemplo, um rebel clown [palhaço rebelde] não deva concorrer a prefeito; sério! E nenhuma razão

\footnotetext{
29 Não posso imaginar um exemplo mais radical para recomendar ao leitor do que o trecho de The Commander's Gait de Marcel Mariën, apresentado por Tom McDonough em The situationists and the city (2009).
} 
para que iniciativas típicas do Occupy não devessem buscar alvos espaciais amenos, os quais poderiam se tornar espaços sustentáveis de moradia, educação e alimentação. A título de exemplo, Grow Heathrow nasceu da lógica combinada do Camps for climate action e do movimento Transition Towns (MASON; WHITEHEAD, 2012a). Ocupar uma horticultura abandonada em Sipson, próximo a Londres, e fazer plantações, o caráter produtivo de Grow Heathrow significa que possui apoio da comunidade local, e também conquistou uma aprovação popular mais ampla. Então, se as autoridades obtêm uma ação de despejo, esta será uma decisão muito impopular, a qual será combatida.

O futuro, observa Hodkinson, é indefinido e deve ser orientado pelos princípios dos comuns. Não poderá haver nenhuma relação estabelecida entre táticas de resistência e uma estratégia utópica porque, primeiramente, a resistência deve inspirar uma massa crítica de pessoas, que conceberá aquela estratégia coletivamente. Buscar o possível significa que uma série de pequenas intervenções táticas poderá lograr uma massa crítica, redefinindo como nosso ambiente é produzido. Por fim, o objetivo é, como declarei, o de fazer da cidade um espaço de política participativa do bem comum, um espaço de justiça e de sustentabilidade ambiental, mas também um espaço de liberdade, diferença, dissenso, de ironia e diversão. A agenda de pesquisa para acadêmicos que busquem fazer ressurgir uma cidade sustentável, então, deveria ser uma pesquisa-ação com a comunidade, com vistas a que se subverta sua recuperação.

\section{Referências}

AGYEMAN, Julian, BULLARD, Robert; EVANS, Bob. (Orgs.). Just sustainabilities: development in an unequal world. London: Earthscan, 2003.

AGYEMAN, Julian; EVANS, Bob. Just sustainability: the emerging discourse of environmental justice in Britain? London: The Geographical Journal, v. 170, n. 2, p. 155$164,2004$.

BACON, Francis. New Atlantis. In: BRUCE, Susan. (Org.). Three early modern utopias. Oxford: OUP, 2008. 
BLASSINGAME, Lurton. Sustainable cities: oxymoron, utopia, or inevitability. London: The Social Sciences Journal, v. 35, n. 1, p. 1-13, 1998.

BRUCE, Susan. (Org.). Three early modern utopias. Oxford: OUP, 2008.

BULLEN, Anna; WHITEHEAD, Mark. Negotiating the networks of space, time and substance: a geographical perspective on the sustainable citizen. London: Citizenship Studies, v. 9, n. 5, p. 499-516, 2005.

BUTTEL, Frederick. Ecological modernisation as social theory. Oxford: Geoforum, n. 31, p. 57-65, 2000.

CALLENBACH, Ernest. Ecotopia. Berkeley: Banyan Tree Books, 1975.

CALLENBACH, Ernest. Ecotopia emerging. Berkeley: Banyan Tree Books, 2004.

CAMPANELLA, Tommaso. The city of the sun. Berkeley: University of California Press, 1981.

CARLSSON, Chris. Nowtopia: how pirate programmers, outlaw bicyclists and vacant lot gardeners are inventing the future today! Oakland: AK Press, 2008.

CARLSSON, Chris; MANNING, Francesca. Nowtopia: strategic exodus. San Francisco: Antipode, v. 42, n. 4, p. 924-953, 2010.

CHATTERTON, Paul. 'Give up activism' and change the world in unknown ways: or, learning to walk with others on uncommon ground. San Francisco: Antipode, v. 38, n. 2, p. 259-281, 2006.

COVERLEY, Merlin. Utopia. Harpenden: Pocket Essential, 2010.

DEBORD, Guy. Society of the spectacle. Detroit: Black \& Red, 1983.

EVANS, Bob; JOAS, Marko; SUNDBACK, Susan; THEOBALD, Kate. Governing sustainable cities. London: Earthscan, 2005.

FISHER, Dana; FREUDENBURGH, William. Ecological modernisation and its critics: assessing the past and looking towards the future. London: Society and Natural Resources, v. 14, n. 1, p. 701-709, 2001.

GALLOPIN, Gilberto. Linkages between vulnerability, resilience and adaptive capacity. Santiago: Global Environmental Change, n. 16, p. 293-303, 2006. 
GIRARDET, Herbert. Creating sustainable cities. Totnes: Green Books, 1999.

GIRARDET, Herbert. Cities people planet. Chichester: Wiley-Academy, 2004.

GOLDSMITH, Edward. A blueprint for survival. London: Penguin, 1973.

GUY, Simon; MOORE, Steve. Sustainable architecture and the pluralist imagination. London: Journal of Architectural Education, v.1, n. 1, p. 15-23, 2007.

HARVEY, David. Spaces of hope. Berkeley: University of California Press, 2000.

HODKINSON, Stuart. Housing in common: in search of a strategy for housing alterity in England in the 21st century. In: FULLER, Duncan; JONAS, Andrew; LEE, Roger (Orgs.). Interrogating alterity: alternative economic and political spaces. Farnham: Ashgate, 2010.

HUBER, Joseph. The rainbow society: ecology and social politics. Frankfurt am Main: Fisher Verlag, 1985.

JACOBY, Russel. The end of utopia: politics and culture in an age of apathy. New York: Basic Books, 1999.

LAURITSEN, Pernille. Christiania. Oslo: Aschehoug, 2002.

LEFEBVRE, Henri. The production of space. Oxford: Blackwell, 1991.

MASON, Kelvin. Finding hope in No-hopenhagen. London: Peace News, jan., 2010.

MASON, Kelvin; WHITEHEAD, Mark. Between here and there: mobilizing urban vulnerabilities in climate camps and transition towns. In: DOOLING, Sarah; SIMON, Gregory (Orgs.). Cities, nature and development: the politics and production of urban vulnerabilities. Farnham: Ashgate, v. 5, n. 24, $2012 a$.

MASON, Kelvin; WHITEHEAD, Mark. Transition urbanism and the contested politics of the spatial practice. San Francisco: Antipode, v. 44, n. 2, p. 493-516, 2012 b.

MASSEY, Doreen. World city. Cambridge: Polity, 2007.

MCCLOUD, Kevin. Slumming it. Channel 4. 2010. Disponível em <http://www.channel4.com/programmes/kevin-mccloud-slumming-it >. Acesso em: 17 out. 2011. 
MCDONOUGH, Tom. The situationists and the city. London: Verso, 2009.

MERRIFIELD, Andy. Henri Lefebvre: a socialist in space. In: CRANG, Mike; THRIFT, Nigel (Orgs.). Thinking space. Abingdon: Routledge, 2002.

MERRIFIELD, Andy. Magical marxism: subversive politics and the imagination. London: Pluto Press, 2011.

MILES, Malcolm. Urban utopias: the built and social architectures of alternative settlements. Oxford: Routledge, 2005.

MOL, Arthur; SONNENFELD, David; SPAARGAREN, Gert. The ecological modernisation reader. Abingdon: Routledge, 2010.

MOL, Arthur; SPAARGAREN, Gert. Ecological modernisation theory in debate: A review. London: Environmental Politics, v. 9, n. 1, p. 17-49, 2000.

MORE, Thomas. Utopia. In: BRUCE, Susan (Org.). Three early modern utopias. Oxford: OUP, 2008.

MOUFFE, Chantal. The return of the political. London: Verso, 2005.

MURPHY, Joseph. Editorial: ecological modernisation. Oxford: Geoforum, v. 31, n. 3, p. 18, 2000.

NEVILLE, Henry. The Isle of Pines. In: BRUCE, Susan (Org.). Three early modern utopias. Oxford: OUP, 2008.

PEARCE, Fred. Ecopolis now. London: New Scientist, n. 2556, 17 June, 2006.

PEPPER, David. Utopianism and environmentalism. London: Environmental Politics, v. 14, n. 1, p. 3-22, 2005.

PINDER, David. In defence of utopian urbanism: imagining cities after the 'end of utopia'. London: Geografiska Annaler, v. 84b, n. 3-4, p. 229-241, 2002.

PINDER, David. Visions of the city. Edinburgh: Edinburgh University Press, $2005 a$.

PINDER, David. Visions of the city: utopianism, power and politics in twentieth-century urbanism. Edinburgh: Edinburgh University Press, 2005b. 
PINDER, David. Situationism/Situationist Geography. In: KITCHEN, Rob; THRIFT, Nigel. (Orgs.). International encyclopedia of human geography. Oxford: Elsevier, 2009.

SADLER, Simon. The situationist city. Cambridge, Massachusetts: MIT Press, 1999.

SANDEL, Michael. Justice: what's the right thing to do? London: Penguin, 2010.

SANDERCOCK, Leonie. Towards cosmopolis: planning for multicutural cities. Chichester: John Wiley, 1998.

SARGISSON, Lucy. Green utopias of the self and others. London: Critical Review of International Social and Political Philosophy, v. 3, n. 2, p. 140-156, 2000 a.

SARGISSON, Lucy. Utopian bodies and the politics of transgression. London: Routledge, 200ob.

SATTERTHWAITE, David. (Org.). The earthscan reader in sustainable cities. London: Earthscan, 1999.

SCHMID, Christian. Henri Lefebvre's theory of the production of space: towards a threedimensional dialectic. In: GOONEWARDENA, Kanishka; KIPFER, Stefan; MILGROM, Richard; SCHMID, Christian (Orgs.). Space, difference and everyday life: reading Henri Lefebvre. London: Routledge, 2008.

SHIELDS, Rob. Henri Lefebvre. In: HUBBARD, Phil; KITCHEN, Rob; VALENTINE, Gill (Orgs.). Key thinkers on space and place. London: Sage, 2009.

SPANNOS, Chris (Org.). Real utopias. Oakland: AK Press, 2008.

SWYNGEDOUW, Erik. Apocalypse forever: postpolitical populism and spectre of climate change theory. London: Culture \& Society, v. 279, n. 2-3, p. 213-232, 2010.

SZERSZYNSKI, Bronislaw. The post-ecologist condition: irony as symptom and cure. London: Environmental Politics, v. 16, n. 2, p. 337-355, 2007.

THOMAS, Dylan. Do not go gentle into that good night. In: JONES, Daniel (Org.). The poems of Dylan Thomas. New York: New Directions Publishing, 1937.

WCED. Our common future. Oxford: Oxford University Press, 1987.

WHITEHEAD, Mark. Spaces of sustainability: geographical perspectives on the sustainable society. London: Routledge, 2007. 
WHITEHEAD, Mark. Sustainability, Urban. In: KITCHEN, Rob; THRIFT, Nigel (Orgs.). International encyclopedia of human geography. Oxford: Elsevier, 2009.

WHITEHEAD, Mark. The sustainable city: an obituary? On the future form and prospects of sustainable urbanism. In: FLINT, John; RACO, Mike (Orgs.). The future of sustainable cities: critical reflections. Bristol: The Policy Press, 2011.

Recebido em: 04/04/2019

Aprovado em: 27/06/2019

Universidade do Estado de Santa Catarina - UDESC Centro de Ciências Humanas e da Educação - FAED

Revista PerCursos Volume 20 - Número 42 - Ano 2019 revistapercursos@gmail.com 